\title{
Transnational Corporations as Agents of Legal Change: The Role of Corporate Social Responsibility
}

\author{
Neli Frost
}

\begin{abstract}
This article draws on sociological studies of corporate social responsibility, new governance and legal transplant theories to reconsider the role of transnational corporations (TNCs) as regulators and agents of change in the field of human rights. The article demonstrates the potentials of transnational corporations as vehicles for the transplanting of human rights sensibilities in post-colonial settings through the use of corporate social responsibility practices. It does so by reconsidering the institutional role of transnational corporations, not as objects of international human rights regulation, but as actual regulators in this field.
\end{abstract}

\section{Keywords}

Corporate social responsibility, transnational corporations, human rights

\section{Introduction}

Most international human rights law textbooks focus on the state as the primary regulator of human rights and the individual as the subject of those rights. ${ }^{1}$ This statist paradigm which stands at the centre of human rights law is linked to a command-and-control type governance that considers the state as the sole dutybearer and authority with regard to regulation of human rights within its sovereign territory. ${ }^{2}$ Due to this structure, the role of international law in relation to corporate

* I would like to thank Dr. Doreen Lustig for her comments and guidance.

1 Philip Alston, Ryan Goodman and Henry J Steiner, International Human Rights in Context: Law, Politics, Morals (3rd edn, OUP 2007) 1385.

2 Doreen Lustig, 'Three Paradigms of Corporate Responsibility in International Law: The Kiobel Moment' (2014) 12 JICJ 593, 595; See also Robert Baldwin, Martin Cave and Martin Lodge, 'Introduction: Regulation - The Field and the Developing Agenda' in Robert Baldwin, Martin Cave and Martin Lodge (eds), The Oxford Handbook of Regulation (OUP 2010) 6-10. 
actors has primarily been to define the rights and obligations of states in the context of investment issues, ${ }^{3}$ while failing to impose any respective direct international obligations on corporations regarding their involvement in human rights abuses.

This statist paradigm is similarly prevalent in the sociology of human rights and legal transplants and diffusion theories. These theories typically examine the appearance, development and institutionalisation of legal regimes and centre on the social, political and cultural conditions in which legal norms are consolidated and violated. ${ }^{4}$ Sociologists of human rights who explore the multiple ways in which international human rights regimes may influence the design and structuring of domestic regimes primarily centre on legal instruments such as inter-state treaties and on governmental and civil society agents in their assessment and analysis of the various ways in which human rights are mobilised and institutionalised. Their inquiries focus on the ways in which international law shapes state behaviour, the effectiveness of treaty regimes in changing such behaviour, the relationship between ratification of treaties and domestic human rights practices, and the mechanisms of social influence through which states and institutions affect the behaviour of other states. ${ }^{5}$

These studies posed a ground-breaking challenge to the assumption that international human rights law does not make a difference and lacks any real influence in the world. They exposed the importance of international human rights law through their concentration on its influence on mobilisation processes within states: how agents of change and transnational networks used international human rights law to penetrate the sovereign veil and instigate domestic processes of change through social processes other than traditional compliance, such as the changing of political agendas, creating collective action problems and influencing

3 Jennifer A Zerk, Multinationals and Corporate Social Responsibility: Limitations and Opportunities in International Law (CUP 2011).

4 Matthieu Deflem and Stephen Chicoine, 'The Sociological Discourse on Human Rights: Lessons from the Sociology of Law' (2011) 40(1) Development and Society 101.

5 See, eg, Oona Hathaway, 'Do Human Rights Treaties Make a Difference?' (2002) 111 Yale LJ 1935; Ryan Goodman and Derek Jinks, 'How to Influence States: Socialization and International Human Rights Law' (2004) 54(3) Duke LJ 621; Oona Hathaway, 'Why do Countries Commit to Human Rights Treaties?' (2007) 51(4) J Conflict Resol 588; Beth A Simmons, Mobilizing Human Rights: International Law in Domestic Politics (CUP 2009); Sally Engle Merry, 'Gender Justice and CEDAW: The Convention on the Elimination on all Forms of Discrimination Against Women' (2011) 9 Journal of Women of the Middle East and the Islamic World 49; Richard A Nielsen and Beth A Simmons, 'Rewards for Ratification: Payoffs for Participating in the International Human Rights Regimes?' (2015) 59(2) ISQ 197. 
legal decisions. ${ }^{6}$ However, the focus of these human rights scholarships has thus far been mostly on state-driven, public human rights processes as the main source for social change, while often marginalising the role of transnational corporations (TNCs) as agents of change in processes relating to human rights diffusion and institutionalisation.

The present article challenges the prevalent perspectives regarding TNCs' role in international human rights law. Through the analysis of corporate social responsibility practices implemented in Bangladesh following the Rana Plaza disaster, it explores whether TNCs could be considered important players in the acts of ordering the field of human rights. Drawing on the theoretical frameworks of legal transplants, sociological studies of corporate social responsibility, and novel regulatory models, ${ }^{7}$ the article suggests conceptualising TNCs as potential carriers of human rights norms to post-colonial settings, potentially initiating bottom-up changes in human rights standards.

This article explores the way in which TNCs may act as agents of legal change in the transnational arena although not formally possessing public power, and how they may contribute-alongside and in collaboration with states-to the design and enforcement of human rights regimes rather than simply posing a threat to them. This perspective undermines the archetypical dichotomy between publicstatist regulation and market self-regulation in the form of soft law, and offers a collaborative public-private approach to global regulation of human rights. Conceptualising transnational corporations as important regulatory actors in the field of human rights could also serve as a platform to rethink some of the prevailing normative assumptions of the relationship between TNCs and human rights, and raise significant questions regarding our understanding of human rights theories and doctrines in an era of dominant private transnational corporate power.

The article proceeds as follows. Part 2 reviews discussions regarding the primary regulatory actors involved in the designing and structuring of human rights regimes, first from the perspective of classical international human rights law and sociology of human rights, then from the perspective of new governance theories. Drawing on the new governance models, this part will examine TNCs' role as regulatory actors in the field of human rights through means of corporate social responsibility practices. Part 3 characterises this role through the theoretical

6 Simmons (n 5).

7 Orly Lobel, 'New Governance as Regulatory Governance' in David Levi-Faur (ed), The Oxford Handbook of Governance (OUP 2012). 
frameworks of legal transplants and sociology of corporate social responsibility. Part 4 exemplifies this analysis through the Rana Plaza disaster case study, and Part 5 will conclude.

\section{The public/private divide in international human rights discourse and its challenges}

The centrality of the state is one of the most significant characteristics of classic international law. ${ }^{8}$ According to this traditional view, given that states are the primary subjects of international law and its authority is derived from their consent, they retain complete discretion with regard to their sovereign jurisdiction, and have a claim on the monopolistic use of force within their boundaries. ' Consequently, human rights were originally perceived as a matter belonging to the domestic sphere, ${ }^{10}$ often in the context of protecting individuals from the potentially harmful and abusive power of the state, ${ }^{11}$ thereby limiting states' power. ${ }^{12}$ As one international scholar put it:

Human rights are ultimately a profoundly national — not international-issue. States are the principal violators of human rights and the principal actors governed by the regime's norms; international human rights are concerned primarily with how a government treats inhabitants of its own country. ${ }^{13}$

In congruence with this view, the traditional instruments used to set human rights standards and protections are international covenants that oblige states, and

$8 \quad$ Alston, Goodman and Steiner (n 1) 1385.

$9 \quad$ Lustig (n 2) 595.

10 Michelo Hansungule, 'Chapter One: The Historical Development of International Human Rights' in Azizur Rahman Chowdhury and Jahid Hossain Bhuiyan (eds), An Introduction to International Human Rights Law (Brill 2010) 2.

11 August Reinisch, 'The Changing International Legal Framework for Dealing with Non-State Actors' in Philip Alston (ed), Non-State Actors and Human Rights (OUP 2005) 38; See also Chris Jochnick, 'Confronting the Impunity of Non-State Actors: New Fields for the Promotion of Human Rights' (1999) 21 Hum Rts Q 56, 58-59; Nigel Rodley, 'Non-State Actors and Human Rights' in Scott Sheeran and Nigel Rodley (eds), Routledge Handbook of International Human Rights Law (Routledge 2013) 523.

12 Reinisch (n 11) 37-38.

13 Jack Donelly, 'International Human Rights: A Regime Analysis' (1986) 40(3) Int'l Org 599, 616. 
states only, as the contracting parties. ${ }^{14}$ Accordingly, the emphasis in this type of treaty-regime is the sovereign's limited renunciation of national authority and the retention of discretion with regard to the implementation of these internationally agreed upon norms. ${ }^{15}$

Nonetheless, in the face of globalisation processes, privatisation of governmental functions, global mobility of capital and trade liberalisation, as well as the growth of transnational civil society and fragmented centres of power, nonstate actors began to pose new challenges to the traditional state-oriented nature of international human rights law and to the state-individual relationship's centrality in this regime. ${ }^{16}$ TNCs with immense economic powers moved their production sites to places in which local laws were most favourable for them, hence enabling them maximum profit with minimum legal liabilities. ${ }^{17}$ Gradually scholars, lawmakers, civil society agents, activists, and workers' unions called for greater accountability and liability of corporations in international law, especially in the context of labour and human rights in postcolonial settings. The main thrust of their critique was that transnational corporate actors, no less than political governments, pose serious threats to human rights conditions, alongside the limited capacity or unwillingness of some states to introduce domestic legal measures to tame corporate activity. ${ }^{18}$ The recognition that entities other than states and state agents

14 The International Covenant on Civil and Political Rights and the International Covenant on Economic Social and Cultural Rights refer, in their preamble and the ensuing articles, to state parties as those responsible for ensuring the respect and protection of the human rights promoted by the treaties. Such state responsibility is to be employed through the use of states' political power and prerogative, namely legislative, administrative and enforcement powers. International Covenant on Civil and Political Rights (adopted 16 December 1966, entered into force 23 March 1976) 999 UNTS 171 (ICCPR); International Covenant on Economic, Social and Cultural Rights (adopted 16 December 1966, entered into force 3 January 1976) 993 UNTS 3 (ICESCR); See also Reinisch (n 11) 39. Jack Donelly, 'State Sovereignty and International Human Rights' (2014) 28(2) Ethics \& International Affairs 225, 229.

16 Alston, Goodman and Steiner (n 1) 1385.

17 See, eg, Steven R Ratner, 'Corporations and Human Rights: A Theory of Legal Responsibility' (2001-2002) 111 Yale LJ 443; Beth Stephens, 'The Amorality of Profit: Transnational Corporations and Human Rights' (2002) 20 Berkeley J Int'l L 45; David Kinley and Junko Tadaki, 'From Talk to Walk: The Emergence of Human Rights Responsibilities for Corporations at International Law' (2003-2004) 44 Virginia J Int'l L 931; Ronen Shamir, 'Between SelfRegulation and the Alien Tort Claims Act: On the Contested Concept of Corporate Social Responsibility' (2004) 38 Law \& Society Review 635. Shamir (n 17). 
can affect human rights created the need to formulate non-state actors' obligations under international law, holding them liable for violations of human rights. ${ }^{19}$

Accordingly, the legal framework and instruments used in this new human rights discourse had to be adapted to a more diverse analysis of non-state behaviours, among others, those of TNCs operating in multiple jurisdictions. ${ }^{20}$ It is against this backdrop that a wide range of regulatory initiatives tackling the problem of corporate social responsibility emerged as a central concern for international human rights lawyers. These initiatives are categorised by the international human rights scholarship as either hard law mechanisms of statist-public regulation, or soft law mechanisms of private ordering. Within the realm of hard law and public regulation, one can find the Draft Norms on the Responsibilities of Transnational Corporations and Other Business Enterprises with regard to Human Rights, which were eventually rejected by the UN Commission on Human Rights a year after their drafting, ${ }^{21}$ and national legislations such as the Alien Tort Claims Act attempting to impose extra-territorial liability on corporations for violations of human rights overseas. $^{22}$

Alongside such hard law mechanisms, instruments of private ordering proliferated as well. Among these, the human rights scholarship differentiates between soft law, self-regulatory mechanisms, such as voluntary corporate codes of conduct drafted by TNCs themselves, and multi-stakeholder initiatives such as

19 Rodley (n 11) 542; These efforts can be traced back to the trials of leading German industrialists for war crimes after the Second World War. See Ratner (n 17) 448.

20 Reinisch (n 11) 40-42.

21 The Draft Norms were drafted in 2003 by a working group established by the UN SubCommission on the Promotion and Protection of Human Rights with the purpose of creating a treaty-like mechanism which imposed on transnational corporations corresponding legal duties to those of states in their 'respective spheres of activity and influence'. Although imposing independent legal obligations on corporations, states and other international bodies such as the UN remained responsible for assuring corporations' compliance: UN Sub-Commission on the Promotion and Protection of Human Rights, 'Draft Norms on the Responsibilities of Transnational Corporations and Other Business Enterprises with regard to Human Rights' (2003) UN Doc E/CN.4/Sub.2/2003/38/Rev.2; See also John G Ruggie, 'Business and Human Rights: The Evolving International Agenda' (2007) 101(4) AJIL 819.

22 Proposals of bills in Australia, the US and the UK regarding corporate conduct were met with little success, Peter T Muchlinski, Multinational Enterprises and the Law (2nd edn, OUP 2010) 526; and the Kiobel judgment brought an end to American attempts to hold corporations liable for gross violations of human rights under the Alien Tort Claims Act: Kiobel v. Royal Dutch Petroleum Co. 133 S. Ct. 1659 (2013); Shamir (n 17). 
the United Nations' Global Compact and the Global Reporting Initiative. ${ }^{23}$ The large corpus of legal academic literature on corporate social responsibility which emerged in the 1990s concentrated on the normative justifications for such voluntary soft law initiatives and their effectiveness in comparison to the more traditional hard law regulatory frameworks. ${ }^{24}$

In other disciplines, such as management, business ethics or sociology, scholars explore the business case for corporate social responsibility, including different theories conceptualising the interface between business and society, and exploring both theoretically and empirically the financial and social benefits of 'sustainable businesses' and 'good corporate citizenship,', as well as providing social and critical accounts of the meaning and influence of such practices. ${ }^{26}$

23 See the UN Global Compact Office, 'The Ten Principles of the Global Compact' (2004) <http:// www.unglobalcompact.org/what-is-gc/mission/principles> accessed 27 September 2016; The Global Reporting Initiative <http://www.globalreporting.org/Pages/default.aspx > accessed 27 September 2016; Another interesting multi-stakeholder initiative is the Montreux Document, ratified in Switzerland in 2008. The Document was the fruit of a joint initiative of the Swiss government and the International Committee of the Red Cross. The Document is not legally binding and does not affect the existing legal obligations of states under international law, but rather provides states with good practices to promote the compliance of private military and security companies with international humanitarian and human rights law: The Montreux Document on Pertinent International Legal Obligations and Good Practices for States related to Operations of Private Military and Security Companies during Armed Conflict (2008) $<$ https://http://www.icrc.org/eng/assets/files/other/icrc_002_0996.pdf > accessed 23 December 2016.

24 See, eg, Ratner (n 17); Stephens (n 17); Kinley and Tadaki (n 17); Shamir (n 17).

25 See, eg, Elizabeth C Kurucz, Barry A Colbert and David Wheeler, 'The Business Case for Corporate Social Responsibility' in Andrew Crane and others (eds), The Oxford Handbook of Corporate Social Responsibility (OUP 2008) 83; Patricia Illingworth, 'Global Need: Rethinking Business Norms' in Jena Martin and Karen E Bravo (eds), The Business and Human Rights Landscape; Moving Forward, Looking Back (CUP 2016) 175.

26 See, eg, Ronen Shamir, 'Corporate Social Responsibility: Towards a New Market-Embedded Morality?' (2008) 9 Theoretical Inquiries in Law 371; J Hans van Oosterhout and Pursey PMAR Heugens, 'Much Ado About Nothing: A Conceptual Critique of Corporate Social Responsibility' in Andrew Crane and others (eds), The Oxford Handbook of Corporate Social Responsibility (OUP 2008) 197; Jeremy Moon and David Vogel, 'Corporate Social Responsibility, Government and Civil Society' in Andrew Crane and others (eds), The Oxford Handbook of Corporate Social Responsibility (OUP 2008) 303; Tim Bartley, 'Transnational Governance as the Layering of Rules: Intersections of Public and Private Standards' (2011) 12(2) Theoretical Inquiries in Law 517; Alwyn Lim and Kiyoteru Tsutsui, 'Globalization and Commitment in Corporate Social Responsibility: Cross-National Analyses of Institutional and PoliticalEconomy Effects' (2012) 77(1) Am Soc Rev 69; Tim Bartley, 'Transnational Governance and the Re-centered State: Sustainability or Legality?’ (2014) 8 Regulation \& Governance 93. 
These scholarships are not constrained by conceiving states as the sole duty bearers with regard to human rights and rigorously address the obligations of private corporate actors. However, the main puzzle that motivates most studies in such fields focuses as well on the soft law/hard law distinction and its implications for effectively regulating and taming corporate complicity in violation of human rights. This focus on the hard law/soft law puzzle implicitly assumes the corporate actor as an object of international regulation in contrast to the state's classic public regulatory role.

\subsection{New Governance Theories: Private entities as 'law-makers'}

In recent years, a new theoretical framework has emerged that suggests a further paradigm shift with respect to the command-and-control versus market regulation dichotomy in the field of global governance. Governance, as defined by John Ruggie, 'refers to the systems of authoritative norms, rules, institutions and practices by means of which any collectivity, from the local to the global, manages its common affairs. ${ }^{27}$ The new governance model challenges the classical view that the regulatory power of administrative agencies is based on their superior knowledge, and focuses on the increased participation of non-state actors in the process of regulation by promoting collaborative public-private standard-setting. ${ }^{28}$ Within this paradigm, private entities and institutions are regarded as normgenerating subjects, ${ }^{29}$ in contrast to merely the objects of regulation, ${ }^{30}$ thus creating a new division of labour between the state and other social actors. ${ }^{31}$ In other words, rather than conceptualising non-state actors as passive objects of regulation, whose 'agency is limited to choosing whether to comply with the regulations to which they are subjected, ${ }^{32}$ this model endeavours to harness private entities' practices, standard-making, and resources, to ameliorate the effectiveness of regulation. ${ }^{33}$ Business and Human Rights' (2014) 20 Global Governance 5.

28 Lobel, 'New Governance as Regulatory Governance' (n 7) 66-67.

29 ibid.

30 ibid.

31 David Levi-Faur, 'The Global Diffusion of Regulatory Capitalism' (2005) 598 The Annals of the American Academy of Political and Social Science 12.

32 Orly Lobel, 'The Renew Deal: The Fall of Regulation and the Rise in Governance in Contemporary Legal Thought' (2004) 89 Minn L Rev 342, 376.

Lobel, 'New Governance as Regulatory Governance' (n 7) 69. 
The new governance model is often taken to be a response to the process of globalisation, and more specifically, to the failure of international 'old governance ${ }^{34}$ to effectively regulate businesses in the transnational arena. This empirical claim emphasises the way in which the prior, state-centric hierarchical governance model, consisting of treaty-based mandatory regimes had limited capacity in dealing with the challenges of strong economic actors, globalisation, and the attendant societal challenges. ${ }^{35}$ Abbott and Snidal characterised these new regulatory initiatives as having two main characteristics. The first is a central role that private actorsnamely NGOs and private firms-play in forming and designing these regulatory norms (as opposed to that of the state). The second is the voluntary nature of these norms, although they involve the typical functions of administrative statist regulation, such as rule-making, and implementation and imposition of sanctions. ${ }^{36}$

The state, in this new regulatory model, remains a significant actor, albeit not in its role as a top-down commander, but rather as an orchestrator operating through the promotion of networks of different actors and institutions engaging in regulatory activities. ${ }^{37}$ Under the new governance model, the state encourages private actors to draw on their great resources and capacities in order to self-regulate and participate in regulating others through varied forms of private ordering. This decentralisation mechanism works through various networks in which non-state actors are partners in governance and not mere objects of regulation, which, in turn, alleviates the adversarial nature of old governance regulation. ${ }^{38}$ In addition, through the active participation of multiple actors in governance processes, different societal actors become engaged in dialogue and deliberation regarding both the normative and practical aspects of standards-setting. This type of discourse encourages different societal actors to take mutual responsibility for human rights violations. ${ }^{39}$ Amongst these diverse types of regulatory initiatives, the present article will focus on voluntary practices of corporate social responsibility. Vanderbilt J Transnatl L 501. 


\subsection{Corporate Social Responsibility as a form of New Governance}

One of the major focuses of corporate social responsibility practices in the last two decades has been the improvement of labour conditions in developing countries characterised by weak institutions of domestic labour governance. After the exposure of the precarious working conditions in factories manufacturing for corporations such as Nike, Gap and Walmart in the 1990s, a large number of retailers and brands in the apparel, electronics and food industries have adopted codes of conduct establishing standards for working conditions in their supply chain, along with enforcement mechanisms. ${ }^{40}$ These different initiatives offered a way to advance workers' rights on the ground, independently of the legal regime regulating labour conditions in a particular state, and contributed to the local human rights discourse amongst workers, factory managers, trade unions and governmental agents.

The ability of private entities to take part in global regulation of social fields has been recognised by sociologists, ${ }^{41}$ but has not been the focus of the sociology of human rights. The following section offers the conceptual lens of legal transplants to critically explore the regulatory role of corporations and elucidate the ways in which TNCs serve as carriers of human rights norms into post-colonial settings through corporate social responsibility practices and policies.

\section{Legal transplants and corporate social responsibility: Conceptualising corporations' role as agents of legal change}

Although a vast amount of literature has been written both on theories of legal transplants and on the subject of corporate social responsibility, these two frameworks have yet to be discussed in relation to one another. Following the propositions of new governance theories and their perception of private entities' potential role in formulating and designing legal regimes, the following section will offer an explanatory framework for this role and for TNCs' influence on

40 David Vogel, A Market for Virtue: The Potential and Limits of Corporate Social Responsibility (Brookings Institution Press 2005) 75; See also Tim Bartley, 'Corporate Accountability and the Privatization of Labor Standards: Struggles over Codes of Conduct in the Apparel Industry' (2005) 14 Research in Political Sociology 211; Kevin Kolben, 'Dialogic Labor Regulation in the Global Supply Chain' (2015) 36(3) Mich J Intl L 425.

Bartley (n 26). 
shaping human rights norms. It will do so by considering TNCs as agents of legal change, and corporate social responsibility practices as the means to implement such change.

\subsection{What are legal transplants?}

The legal transplant framework typically deals with the movement of law from one jurisdiction to another and the relevant actors in this process of mobilisation of the law. Although originating in Alan Watson's positivist-formalist approach which regards law as mobile and autonomous, bearing no connection to the social circumstances surrounding it, ${ }^{42}$ this legal scholarship has since then evolved to socio-legal approaches assuming legal pluralism, ${ }^{43}$ and challenging the underlying assumptions of Watson's positivist paradigm. ${ }^{44}$

The law, under the socio-legal paradigm, is understood in broader terms to include within its definition forms other than the positive law of the state. ${ }^{45}$ Within the premises of transplanted law, one can find not only state laws and institutions, but also a diffusion of standards, regulations, soft-law, treaties, customs and international agreements. ${ }^{46}$ This pluralistic perception of the law moves away from the notion of the sovereign state as the only creator and carrier of the law and enables the inclusion of a wide array of legal phenomena within the field of

Alan Watson, Legal Transplants: An Approach to Comparative Law (2nd edn, The University of Georgia Press 1993); See also Otto Kahn-Freund, 'On Uses and Misuses of Comparative Law' (1974) 37 MLR 1.

43 Sally Engle Merry, 'Legal Pluralism' (1988) 22 Law Soc Rev 869.

44 Lawrence Friedman, for example, uses the term 'legal borrowing' to undermine the positivist postulations regarding the autonomy of the law. According to Friedman, legal development occurs alongside, and as a function of, social development. See Lawrence Friedman, 'Some Comments on Cotterrell and Legal Transplants' in David Nelken and Johannes Feest (eds), Adapting Legal Cultures (Hart 2001); Amongst these scholars are also ones that do empirical work trying to prove the influence of the law's connections to social structures, on the success of transplants. See, eg, Daniel Berkowitz, Katharina Pistor and Jean-Francois Richard, 'The Transplant Effect' (2003) 51 Am J Comp L 163; Inga Markovitz, 'Exporting Law Reform But Will It Travel?' (2004) 37 Cornell Intl LJ 95; Merris Amos, 'Transplanting Human Rights Norms: The Case of the United Kingdom's Human Rights Act' (2013) 36 Hum Rts Q 386. William Twining, 'Diffusion of Law: A Global Perspective' (2004) 49 J Legal Plur 1; William Twining, 'Social Science and Diffusion of Law' (2005) 32 J Law \& Soc 203. (eds), Adapting Legal Cultures (Hart 2001) 31-32. 
transplantation, ${ }^{47}$ and its conceptualisation as a multi-participant model in which many actors, beyond the bilateral importer and exporter, take part. According to this paradigm, the colonial perception of legal transplants as movements of entire legal systems in a 'top-down' fashion is anachronistic and is not coherent with the reality of a globalised world comprised of transnational networks. ${ }^{48}$

The long road that the legal transplant discourse has taken from Watson's starting point is thus significant. The numerous socio-legal scholars engaged with conceptualising the field have highlighted the complexity of this legal phenomenon as well as the impact of various factors on the configuration of diffusion processes. New research avenues have challenged the positivist postulations regarding the autonomous character of the law, its definitions and sources, and have suggested reviewing the various ties between the law and other disciplines from a pluralistic, socio-cultural and economic standpoint, as a precondition to further discussing the evolution and migration of the law.

Nevertheless, despite the substantial challenges posed by these scholars to the positivist framework, a broader, more explicit discussion of the identity of the carrier is still absent from the legal transplant discourse. In particular, despite specific references to global agents of change, such as NGOs and civil society organisations, the transplant dialogue often continues to revert to the colonial context, considering state-agents as the main carriers of the law. ${ }^{49}$ Within this context, the potential role of TNCs as carriers of human rights norms through means of corporate social responsibility, and consequently, as important regulatory actors in this field, remains unaccounted for.

Conceptualising TNCs' role as carriers may permit breaking free from the prevalent structuralist rhetoric, attempting to base the ability to promote human rights on the rejection of financial power. ${ }^{50}$ According to this rhetoric, economic globalisation supported by neo-liberal ideologies weaken states' ability to regulate

ibid.

48 Margit Cohn, 'Legal Transplant Chronicles: The Evolution of Unreasonableness and Proportionality Review of the Administrations in the United Kingdom' (2010) 58 Am J Comp L 583.

49 See, eg, Jean-Louis Halperin, 'The Concept of Law: A Western Transplant?' (2009) 10 Theoretical Inquiries in Law 333; Ron Harris and Michael Crystal, 'Some Reflections on the Transplantation of British Company Law in Post-Ottoman Palestine' (2009) 10 Theoretical Inquiries in Law 561; Michael D Birnhack, Colonial Copyright: Intellectual Property in Mandate Palestine (OUP 2013).

50 See, eg, Neil Stammers, 'Social Movements and the Social Construction of Human Rights' (1999) 21 Hum Rts Q 980. 
economic and social affairs within their boundaries and thus necessarily hinder the promotion of human rights regimes. In the following section I shall examine the way in which the diffusion of human rights norms by TNCs as a form of legal transplantation undermines this rhetoric.

\section{Applying the theory: The Rana Plaza disaster case study}

Rana Plaza, an eight-storey commercial building in Dhaka, Bangladesh, housed five garment factories and over 5,000 employees. These factories produced garments for some of Europe's and the United States' largest clothing companies. On April 24th 2013, the building collapsed. Over 1,100 people were killed and thousands were injured. Most of the injured suffered from permanent injuries. ${ }^{51}$

\subsection{Historical perspective}

During the 1960s, aiming to maximise profit, Western companies such as Walmart, Gap, Sears, H\&M and Ralph Lauren, initiated extensive processes of out-sourcing. By relocating their production sites from the Global North to postcolonial economies (mainly in the Far East), they profited from significantly cheaper labour costs. These economies enabled Western corporations to build on 'fast fashion' production models while enjoying flexible policies and a disciplined workforce who provided the same products for a fraction of the price in a fraction of the time. ${ }^{52}$

51 Human Rights in Supply Chains: A Call for a Binding Global Standard on Due Diligence (2016) <http://www.hrw.org/report/2016/05/30/human-rights-supply-chains/call-bindingglobal-standard-due-diligence > accessed 27 September 2016.

The 'fast fashion' model was born as a retail strategy designed to reduce the retailer's amount of stock, so that displays would be altered every 4-6 weeks instead of once every 2-4 seasons. After the displays are replaced, prices are cut down and the clothes are moved to be sold in outlet stores. This model enables the retailer to sell his merchandise at a higher preliminary price as well as to provide a more versatile display of garments throughout the year. See Ian M Taplin, 'Who is to Blame? A Re-Examination of Fast Fashion After the 2013 Factory Disaster in Bangladesh' (2014) 10(1/2) Critical Perspectives on International Business 72, 74-75; See 
Bangladesh, where the average minimum wage for a worker in the garment industry at the time of the Rana Plaza disaster was less than US $\$ 40$ a month, ${ }^{53}$ is one of the countries in which production costs are the lowest in the world. Benefitting from changes in global regulations of the garment industry and from bilateral agreements with the United States granting it relief on export taxes, it became one of the world's largest garment exporters. ${ }^{54}$ Its garment industry comprises $80 \%$ of its annual exports, produces US $\$ 20$ billion, and employs approximately four million workers in over 5000 factories. ${ }^{55}$

Although considered a parliamentary democracy, Bangladesh is still seeing massive violations of human rights in its territory. ${ }^{56}$ Labour legislation has been built piece by piece, but has not been adjusted to Bangladesh's joining of the global market arena. ${ }^{57}$ In 1992 a special governmental commission began trying to amend Bangladeshi labour legislation with the purpose of creating one coherent comprehensive code. In 2006, the Bangladesh Labour Act was enacted regulating various matters such as the minimum wage, working hours, child labour, workers' safety and more. Nevertheless, the government was concerned that enforcing the Labour Act on corporations would cause them to transfer their production sites elsewhere. These concerns withheld the government from enforcing its

also Jason Burke, 'Rana Plaza: one year on from the Bangladesh factory disaster' The Guardian (London, 19 April 2014) <http://www.theguardian.com/world/2014/apr/19/rana-plazabangladesh-one-year-on> accessed 27 September 2016.

53 The minimum wage was later raised to US\$68 a month. Tamanna Rubya, 'The Ready-Made Garment Industry: An Analysis of Bangladesh's Labor Law Provisions After the Savar Tragedy' (2015) 40(2) Brooklyn J Int'l L 685, 686; Alexandra Rose Caleca, 'The Effects of Globalization on Bangladesh's Ready-Made Garment Industry: The High Cost of Cheap Clothing' (2014) 40(1) Brooklyn J Int'l L 279, 297.

54 The liberalisation of trade prompted a decline in global regulation of the garment and clothing industries. Bangladesh, which was the beneficiary of bilateral trade agreements under MultiFibre Arrangements with the United States, enjoyed a steady growth of its garment industry, especially in light of the deceleration of China's production abilities due to lack of work force. See Taplin (n 52) 75-76.

55 Caleca (n 53) 287-88; Rubya (n 53).

56 See, eg, US Department of State Bureau of Democracy, Human Rights and Labor, 'Country Reports on Human Rights Practices for 2014: Bangladesh' (2014) <http://www.state.gov/j/ $\mathrm{drl} / \mathrm{rls} / \mathrm{hrrpt} /$ humanrightsreport/index.htm?year=2015\&dlid=25295 $>$ accessed 27 September 2016.

57 Caleca (n 53) 299-303. 
new standards on corporations, thus enabling factory owners to violate them systematically. ${ }^{58}$

With the expansion of the garment industry, production processes became gradually decentralised, thus weakening the connection between the workers and the corporations for which they manufacture. This enabled TNCs to easily distance themselves from legal liability for violations of labour regulations and minimum wage requirements. ${ }^{59}$ Nonetheless, after the Rana Plaza disaster and the media frenzy that ensued, the question of TNCs' legal liability began to arise.

\subsection{The Disaster}

The investigation conducted by local authorities following the disaster had revealed the building's collapse was a result of the illegal construction of additional floors occupied by several thousand workers. ${ }^{60}$ As land values in Bangladesh rocketed following the rapid opening of factories to meet Western production demands, Mohammad Sohel Rana, the building owner, had used his political clout to illegally obtain title for the land on which Rana Plaza was built and the construction permit for the upper floors. ${ }^{61}$ On the eve of the collapse, Rana Plaza factories were evacuated on police orders following complaints regarding cracks in their walls. An engineer was summoned to the scene and determined the building to be dangerous and in need of evacuation until a more extensive inquiry could be conducted. ${ }^{62}$ However, the following day, workers were sent back into the building

ibid.

59 See NYU Stern Center for Business and Human Rights, 'Rana Plaza. Factory Safety and Workers' Rights in the Apparel Supply Chain Two Years Later' (NYU Report) <http://bhr.stern. nyu.edu/bangladesh $>$ accessed 27 September 2016.

Jim Yardley, 'Report on Deadly Factory Collapse in Bangladesh Finds Widespread Blame' The New York Times (22 May 2013) <http://www.nytimes.com/2013/05/23/world/asia/report-onbangladesh-building-collapse-finds-widespread-blame.html> accessed 5 January 2017. Jim Yardley, 'The Most Hated Bangladeshi, Toppled From a Shady Empire', The New York Times (30 April 2013) <http://www.nytimes.com/2013/05/01/world/asia/bangladeshgarment-industry-reliant-on-flimsy-oversight.html> accessed 5 January 2017; Broken Dreams: OdhiKar, A Report on the Rana Plaza Collapse, Fact Finding Report, 19 June 2013 <http://1dgy051vgyxh41o8cj16kk7s19f2.wpengine.netdna-cdn.com/wp-content/uploads/ 2013/06/Fact-finding_RMG_Rana-Plaza_Eng.pdf > accessed 5 January 2017.

62 Jim Yardley and Julfikar Ali Manik, 'Bangladesh Arrests Engineer Who Warned of Dangers' The New York Times (New York, 2 May 2013) <http://www.nytimes.com/2013/05/03/world/ asia/engineer-arrested-in-bangladeshi-building-collapse.html $>$ accessed 27 September 2016. 
by factory owners under the threat of monthly salary deductions for those who refused to resume their work. ${ }^{63}$ The factory owners, ${ }^{64}$ operating under enormous pressure from western companies to meet their quotas, ${ }^{65}$ sought to avoid losing working hours necessary for achieving those quotas. ${ }^{66}$ The government's first investigation revealed that vibrations of the giant generators in the factories caused the building (whose rickety infrastructure was built, as aforementioned, against existing regulations) to collapse, in what was termed Bangladesh's worst industrial accident. ${ }^{67}$ The collapse killed over 1,100 of Rana Plaza's workers, injured thousands, and left many others severely traumatised.

Approximately two years after the collapse of Rana Plaza, in June 2015, the Bangladeshi authorities served indictments against the perpetrators involved in the collapse. ${ }^{68}$ However, beyond the criminal charges brought against those involved directly in the omissions leading to the disaster, the Rana Plaza case led to an additional series of events relevant to this article's context. In June of the same year, two months after the collapse, the American government announced a programme suspending Bangladesh's trade privileges due to concerns regarding the safety and

63 Arun Devnath and Mehul Srivastava, "Suddenly the floor wasn't there," Factory Survivor Says' Bloomberg (New York, 25 April 2013) <http://www.bloomberg.com/news/articles/201304-25/-suddenly-the-floor-wasn-t-there-factory-survivor-says > accessed 27 September 2016; Dave Jamieson, 'Rana Plaza Survivor Left with Debilitating Trauma, Mere \$519 In Compensation So Far' The Huffington Post (19 March 2014) <http://www.huffingtonpost. com/2014/03/19/rana-plaza-compensation_n_4994370.html> accessed 27 September 2016.

64 Amongst the factory owners, there were ministers, former ministers, members of parliament, military generals and university vice chancellors: Caleca (n 53) 296.

65 Amongst others, Primark, JC Penny, Benetton and Joe Fresh. See Clare O'Connor, 'These Retailers Involved in Bangladesh Factory Disaster Have Yet to Compensate The Victims' Forbes (New Jersey, 26 April 2014) <http://www.forbes.com/sites/clareoconnor/2014/04/26/ these-retailers-involved-in-bangladesh-factory-disaster-have-yet-to-compensate-victims $>$ accessed 27 September 2016.

66 Julfikar Ali Manik, Steven Greenhouse and Jim Yardley, 'Western Firms Feel Pressure as Toll Rises in Bangladesh' The New York Times (New York, 25 April 2013) <http://www.nytimes. com/2013/04/26/world/asia/bangladeshi-collapse-kills-many-garment-workers.html> accessed 27 September 2016.

67 'Bangladesh factory collapse toll passes 1,000' BBC News (London, 10 May 2013) <http://www. bbc.com/news/world-asia-22476774> accessed 27 September 2016.

68 Abigail Elise, 'Rana Plaza Disaster Update: Owner Sohel Rana Charged with Murder in Building Collapse That Killed 1,129' International Business Times (New York, 31 May 2015) $<$ http://www.ibtimes.com/rana-plaza-disaster-update-owner-sohel-rana-charged-murderbuilding-collapse-killed-1945446> accessed 27 September 2016; 'Bangladesh murder trial over Rana Plaza factory collapse’ BBC News (London, 1 June 2015) <http://www.bbc.com/news/ world-asia-32956705> accessed 27 September 2016. 
working conditions of the textile industry and its failure to uphold international labour standards. ${ }^{69}$ Bangladesh was one of 125 countries that received tax relief under the Generalised System of Preferences (GSP). The GSP programme was established in an American attempt to safeguard international labour standards, enabling Bangladesh to export 5,000 products to the US-who purchases $25 \%$ of its yearly export-tax-free. ${ }^{70}$ This decision of the American government was obtained following enormous pressure from international worker organisations and NGOs on the American administration to express its dissatisfaction with Bangladeshi working conditions. Despite differences between government and state department officials regarding the consequences of such actions, and the strong resistance of the Bangladeshi government, the American government decided to execute it. ${ }^{71}$

Although this sanction on behalf of the American government was rather symbolic given that it did not apply to the import of garments and affected less than $1 \%$ of the American import from Bangladesh, the American government assumed that revoking Bangladesh's tax benefits would encourage European states to impose appropriate sanctions, thus creating the necessary pressure to change the Bangladeshi norms of protecting human and worker rights. ${ }^{72}$

This move by the American government led the Bangladeshi government to amend the 2006 Labour Law. The amendments included mostly changes in worker safety provisions and the workers' freedom to join trade unions. Among these amendments, requirements regarding better regulation and supervision of factory safety were introduced, as well as training, accident report mechanisms, and the stationing of medical centres in certain factories. ${ }^{73}$ However, these amendments, induced by state action, did not sufficiently ameliorate human and worker rights standards. Many of them were technical in essence and those which did include substantive changes lacked satisfactory enforcement mechanisms. Mainly what (New York, 27 June 2013) <http://www.nytimes.com/2013/06/28/business/us-to-suspendtrade-privileges-with-bangladesh-officials-say.html> accessed 27 September 2016.

The GSP was an initiative designed to encourage financial globalization through attaching certain benefits such as reduced tariffs and foreign investments with the upholding of labour standards. The programme was initiated by the United Nations Conference on Trade and Development (UNCTAD). See Lisa Clay, 'The Effectiveness of the Worker Rights Provisions of the Generalized System of Preferences: The Bangladesh Case Study' (2001) 11 Transnat'l L \& Contemp Probs 175; See also Greenhouse (n 69).

71 Greenhouse (n 69).

72 ibid.

73 Rubya (n 53) 693-99. 
was missing was increased sanctions against factory owners and individuals who violated the law, which remained especially lenient. ${ }^{74}$

Alongside the aforementioned statist regulatory intervention, another important sphere in which measures were taken after the Rana Plaza disaster was the corporate one. As a direct response to the collapse, a group of American corporations established the Alliance for Bangladesh Worker Safety ('the Alliance'). ${ }^{75}$ The purpose of this initiative was to promote the safety level in Bangladeshi garment factories in order to prevent the recurrence of disasters like Rana Plaza in the future. The Alliance's members pledged to provide a total of US $\$ 100$ million in financing to factories in their supply chain in order to ameliorate working conditions in Bangladesh, and over 50 million dollars in finance to local banks in order to increase lending to garment factories undertaking remediation of the deficiencies and shortcomings in the existing factories. ${ }^{76}$ Moreover, the Alliance publishes annual reports of the progress of its goals. In September 2015, the Alliance reported that it had conducted safety inspections in 661 factories, 22 of which remain under inspection and may close due to their safety conditions; 414 factories had introduced hotlines in order to respond to employee complaints; 597 factories had conducted worker safety training; and the Alliance had given US $\$ 100$ million to factories in their supply chain. ${ }^{77}$

Another initiative established following Rana Plaza was the Accord on Fire and Building Safety in Bangladesh ('the Accord'). ${ }^{78}$ The Accord was signed as a binding agreement between TNCs, professional unions and NGOs with the purpose of improving safety conditions in the garment industry in Bangladesh. The Accord obligated its members to act in favour of factory safety, conduct inspection plans, transparency and reporting regarding their findings, and promotion of employees through the proper training of the management of hotlines. In addition, the Accord has an enforcement mechanism similar to that of international treaties

74 ibid; See also NYU Report (n 59).

75 The Alliance for Bangladesh Worker Safety <http://www.bangladeshworkersafety.org> accessed 27 September 2016.

76 Alliance for Bangladesh Worker Safety, 'Remediation' (2017) <http://www. bangladeshworkersafety.org/en/what-we-do/remediation> accessed 16 January 2017.

77 Alliance for Bangladesh Worker Safety, 'Protecting and Empowering Bangladesh's Garment Workers. Second Annual Report' (September 2015) <http://www.bangladeshworkersafety.org/ files/Alliance Second Annual Report, Sept, 2015.pdf> accessed 27 September 2016.

78 ACCORD, 'Welcome to the Accord' (2017) <http://bangladeshaccord.org/> accessed 1 January 2017. 
between states, including a dispute-settlement and violations arbitration system between the members of the Accord. ${ }^{79}$

Alongside these two initiatives, some of the corporations for which the Rana Plaza garment factories manufactured contributed funds through the Rana Plaza Donors Trust Fund. ${ }^{80}$ The fund, established by the International Labour Organization (ILO) together with authorities in the Bangladeshi government, authorities in the textile industry, TNCs and NGOs, promotes donations to the Rana Plaza victims and their families. The damages calculations are done according to ILO standards. ${ }^{81}$ Among the donor corporations, international brand names such as Walmart, United Colors of Benetton, Gap, Primark and more can be found. ${ }^{82}$

\subsection{Corporate social responsibility policies post Rana Plaza - a legal transplant?}

The literature on Rana Plaza tends to concentrate, in its analysis of the corporate initiatives following the disaster, on the challenges TNCs pose to human and labour rights regimes, and on questions regarding the effectiveness of soft-law measures as opposed to states' obligations in the prevention of the recurrence of such tragedies. ${ }^{83}$ This article, however, wishes to question whether it is possible to conceptualise the Accord, the Alliance and the Donors Trust Fund as backpacks in which TNCs have managed to carry human rights norms to Bangladesh as legal transplants. The article suggests that, by embracing a pluralistic, socio-legal view of the legal transplants field, one may perceive the norms and practices that the corporate initiatives detailed above attempted to implement as legal transplants in the field of human rights that are embedded in the wider regulatory frameworks of human and labour rights in Bangladesh.

Rubya (n 53) 709-14.

The Rana Plaza Donors Trust Fund, <http://www.ranaplaza-arrangement.org/fund > accessed 27 September 2016.

For further information on the Fund's operations, see 'Terms and Conditions of the Rana Plaza Donors Trust Fund' (2014) <http://ranaplaza-arrangement.org/fund/termsandconditions> accessed 27 September 2016.

'Rana Plaza Arrangement: Donors' <http://www.ranaplaza-arrangement.org/fund/donors> accessed 27 September 2016; Steven Greenhouse, ' 3 Retailers Give Aid to Bangladesh Workers' The New York Times (28 March 2014) <http://www.nytimes.com/2014/03/29/business/ international/3-retailers-give-to-aid-bangladesh-workers.html?hpw\&rref=business\&_r=1> accessed 27 September 2016.

Taplin (n 52); Caleca (n 53). 
One of the most significant contributions of the Accord and the Alliance was the amelioration of working safety conditions in accordance with Article 7 of the International Covenant on Economic Social and Cultural Rights which recognises a person's right to enjoy minimal working conditions, such as safety at work. ${ }^{84}$ The reports published by the Accord indicate that, as of February 2016, safety inspections were conducted in 1,326 factories. ${ }^{85}$ After conducting these safety inspections, including fire, electricity and structure safety, their findings are shared with factory owners, the signatory companies and worker representatives. The companies, together with the factory owners, later devised the Corrective Action Plans, detailing the remedial actions to be taken, a timeline for the proposed amendments and a financial plan to support them. The plans are then brought to engineers on behalf of the Accord for final approval. By November 2015, 1,195 Corrective Action Plans had been updated after follow-up inspections and approximately 20,000 amendments were made accordingly. ${ }^{86}$ Moreover, the Accord delineates an equal participation of workers' mechanism concerning factory safety management by placing factory employees in health and safety commissions and involving them in the factories' inspection reports. ${ }^{87}$

The Alliance lacks the obligatory and enforcement mechanisms of the Accord and is criticised as such. ${ }^{88}$ Such criticism is in line with international human rights scholars' statist perception and their clear distinction between hard law and soft law mechanisms, as well as their perception of the relevant regulatory actors who should participate in human rights regulation. However, the Alliance reported, like the Accord, actual progress with regard to workers' right to take part in shaping their employment conditions according to the ILO's fundamental principles. ${ }^{89}$ Over 400 employees were trained in using the hotline, enabling them to anonymously report any deficiency in working conditions such as minimum wage and working

85 Accord on Fire and Building Safety in Bangladesh, 'Quarterly Aggregate Report' (25 February 2016) <http://bangladeshaccord.org/wp-content/uploads/Quarterly-Aggregate-Report-25February-2016.pdf> accessed 27 September 2016.

86

87 Mark Anner, Jennifer Bair and Jeremy Blasi, 'Towards Joint Liability in Global Supply Chains: Addressing the Root Causes of Labor Violations in International Subcontracting Networks' (2013-2014) 35 Comp Lab L \& Pol'y J 1, 29.

88 Caleca (n 53) 306-07.

89 The ILO, 'Declaration on Fundamental Principles and Rights at Work' (18 June 1998, annex revised 15 June 2010) <http://www.ilo.org/declaration/lang--en/index.htm> accessed 27 September 2016. 
hours. In addition, the Alliance initiated a pilot programme in twelve factories, establishing a democratically elected workers' representational committee in charge of safety and health at work issues. ${ }^{90}$

Many of the safety provisions promoted by the Accord and the Alliance were anchored in the Bangladeshi Labour Law 2006, and as aforementioned, most of them were amended in the 2013 amendment of the Law to provide better protection following the Rana Plaza disaster and the international pressure that ensued. Nonetheless, for many reasons, the law revealed itself as extremely limited when it came to enforcing its provisions. ${ }^{91}$

Due to this limitation, the Accord's and Alliance's ability to regulate issues of workers' safety and safeguard human rights norms as a new form of corporate social responsibility should be noticed. These initiatives could be regarded as de facto contributing to the infusion of globally recognised, treaty-based, human and worker rights norms, bottom-up, where state legislation failed to solely implement them top-down. As such, TNCs can be perceived as actively contributing to the institutionalisation of human rights in Bangladesh, although doing so through non-formal, non-binding, voluntary impositions of human rights norms.

This conclusion resonates with claims made by new governance theorists regarding the effectiveness of public-private, multi-actor collaborative regulation. According to transnational new governance theories, the new voluntary regulatory initiatives, such as the Accord and the Alliance, which are governed by firms and industry groups together with governments and NGOs (as opposed to traditional inter-state treaties or trans-governmental networks of state officials), are more conducive to information-sharing and learning than the state-centred, centralised old governance regulatory mechanisms. They allow policies to be tailored to the specific needs of the local population and local conditions rather than the enforcement (or lack of) uniform rules, ${ }^{92}$ which, as previously stated, have failed in Bangladesh to make a substantial difference on the ground.

91 One of the main reasons for the failure to implement and uphold the labour legislation's provisions is government corruption. A substantial part of factory owners and other authorities in The Bangladesh Garment Manufacturers and Exporters Association are politicians belonging to two of the biggest parties in Bangladesh. William Gomes, 'Reason and responsibility: The Rana Plaza collapse' openSecurity (9 May 2013) <http://www. opendemocracy.net/opensecurity/william-gomes/reason-and-responsibility-rana-plazacollapse > accessed 27 September 2016. 
The collaboration between TNCs on the one hand, together with NGOs on the other, allows these two types of actors to each pursue their complementary goals. Initiatives such as the Accord and the Alliance permit the NGOs involved to encourage and sponsor higher labour standards in Bangladesh while also enabling the TNCs in such partnerships to enjoy self-regulation, rather than an imposed one. In turn, this results in the creation of joint standards that have the potential, not only to be more effectively implemented than if they were advocated by NGOs alone, but also more legitimate than codes formulated solely by corporations since they are backed by the normative legitimacy of the NGOs. ${ }^{93}$ Moreover, TNCs' willingness to contribute funds to advance the Accord and the Alliance's purposes, and to compensate the Rana Plaza victims, signals a clear recognition of their liability with regard to violations of human and worker rights. Subject to more empirical research, this recognition has the potential to promote local human rights discourse by empowering local populations, and educating them regarding their identity as right-holders. ${ }^{94}$

This suggests that, for all practical purposes, the initiatives described above should be regarded as a type of legal transplant. The model proposed by this article of the current transplant, in the spirit of the broader models offered by socio-legal scholars, recognises the migration of a variety of legal phenomena (standards, ideologies, and practices), from multiple sources (international treaties and principles) which pass through multiple levels (from the transnational/ international to the state and the sub-state) in formal and informal ways, through TNCs and with the help of international organisations, in an ongoing collaborative fashion. ${ }^{95}$ The legal transplant in this case reaches the receiving state through corporate social responsibility practices adopted by the member corporations of the Accord and the Alliance, and are accepted with the help of the local citizenry through means of transparency and cooperation.

ibid.

94 The recognition of the victims' right to receive remuneration for injuries incurred upon them in the course of their work is compatible with the ILO's Employment Injury Benefits Convention: see Convention (No 121) concerning benefits in the case of employment injury (adopted 8 July 1964, entered into force 28 July 1967) 602 UNTS 260; See also Francesca Rheannon, 'The Lessons of Rana Plaza for CSR: Worker Empowerment the Key to Safety?' CSRwire (20 May 2013) <http://www.csrwire.com/blog/posts/854-the-lesson-of-rana-plazafor-csr-worker-empowerment-the-key-to-safety> accessed 27 September 2016. 
It should be emphasised that the recognition of TNCs' role as potential carriers of human rights norms does not assume that corporations are the sole and first carriers to import such norms to countries lacking them. Obviously, a legislative framework recognising some of these rights and principles imported by TNCs following Rana Plaza existed beforehand, and as aforementioned, governmental responses to the disaster were also quick to ensue. However, and counterintuitively perhaps, the involvement of TNCs proved pivotal in shaping the local legal framework by means of transplantation of specific human rights practices in the working routine of these factories.

In line with new governance theorists, this conclusion regarding corporate legal transplantation draws our attention to the probabilities of success of such 'corporate transplants' as compared to those that originate from the state. Sociolegal scholars of legal transplants frequently discuss the important connection between the transplanted law and other social structures in predicting successful acceptance of the transplant. ${ }^{96}$ Within this framework, the larger the gap between the transplanted legal norm and the recipient society's social structures, the more difficult for the transplanted norm to be successfully implemented. This view has led scholars to doubt the viability of legal transplants altogether. ${ }^{97}$

This socio-legal logic may indeed explain the difficulties in human rights reception in Bangladesh by statist channels. Meaning, the gap between the social structures of a developing state such as Bangladesh and the rationales standing at the base of human rights norms creates a true hardship for the proper reception and implementation of human rights by means of signing and ratifying international treaties. Indeed, Bangladeshi attempts to make changes in labour legislation following Rana Plaza, in a manner that will ensure worker safety and rights, has failed to produce any change. The gap between the rationales at the base of these constitutional and legal changes and the economic structures in Bangladesh which dictate workers' reality and conditions, were far too great to successfully accept such changes.

Gunther Teuber and Otto Kahn-Freund discuss the importance of the ties between the law and other social structures in the receiving state such as politics, economy, science and culture, to the success of the transplant. Gunther Teubner, 'Legal Irritants: Good Faith in British Law or How Unifying Law Ends Up in New Divergences' (1998) 61 MLR 11; See also Kahn-Freund (n 42).

97 See, eg, Pierre LeGrand, 'What Legal Transplants?' in David Nelken and Johannes Feest (eds), Adapting Legal Cultures (Hart 2001). 
Socio-legal scholars focus primarily on the state level and mark the agents of change-carriers of legal transplants-as the state's agents alone. In the corporate context, nonetheless, the legal transplant process occurs within the premises of the 'corporate greenhouse'. The promotion of human rights is not done at the state level, trickling down through the state's institutions to civil society, but rather bottomup, through the corporate venue. In other words, it is the corporate entity rather than the state that instigates the legal transplantation of human rights norms by voluntarily adhering to internationally accepted standards and providing its employees with their corresponding rights. In this state of affairs, the society with which the legal norm has to be connected in order to guarantee the transplant's success is the 'corporate society' or the corporate arena. This arena has a priori more liberal characteristics, so as to potentially reduce the gap between the 'social structures' of the corporation and the western-liberal-originated human rights norms that are assimilated through them. One may thus suppose that the same 'corporate liberal arena' may serve as a more fertile environment for the reception of liberal human rights norms by its employees than the state arena in which these norms are often disconnected from their social and cultural structures.

This assumption might spur new thoughts with regard to the field of the sociology of human rights. The proposed discussion of Rana Plaza and the influence of corporations on the local promotion of human rights after the disaster does not focus solely on normative questions of what is appropriate or just, but aims to describe an additional link in the development of human rights regimes in Bangladesh. The acceptance of the proposition according to which TNCs may contribute, through corporate social responsibility practices, to the infusion of human rights norms enriches our understanding of the variety of ways through which human rights are defined and the web of actors that take part in their design and institutionalisation. In other words, the conceptualisation of corporate social responsibility as a legal transplant leads to understanding that human rights regimes are not only formed through state-reception of international treaties, and the influence of transnational networks of NGOs, but through the commercial activity of TNCs as well.

This conclusion undermines the archetypical perception of TNCs and their operation as necessarily posing a threat to human rights regimes. On this view, the threat to human rights regimes is inherent to economic power and global capitalism. ${ }^{98}$ However, the Rana Plaza case challenges the pessimist assumptions 
associated with this paradigm, and demonstrates how TNCs, holding great economic power, have the potential to serve as regulatory agents influencing the diffusion and design of human rights standards.

TNCs' actions following Rana Plaza in the form of the Accord, the Alliance and the Donors Fund, not only contribute, within a wider regulatory framework, to the promotion of safety standards and employee status, but also have the potential to affect human rights discourses in Bangladesh and to create new understandings amongst the local population regarding the universal rights to which they are entitled. Socio-legal empirical research in the field of human rights should thus focus on the possible ways in which the implementation of corporate social responsibility practices may flush out the gap between the governmental and legal rhetoric and the true situation on the ground. The recognition of the existence of a universal system of rights which are owned by the workers as such can serve as a platform for social mobilisation by re-designing workers' ability to fight locally for their rights and demand the state for a practical implementation of the law in the books. ${ }^{99}$ The case of Rana Plaza, therefore, suggests that, contrary to the typical structuralist stand, economic power does not necessarily only violate human rights, but may, under certain conditions, improve them. ${ }^{100}$

Alongside the TNCs which strove, after the disaster, to take part in initiatives to ameliorate conditions and standards in garment factories, there were also corporations such as the Walt Disney Company who decided, as part of their corporate social responsibility policy, to relocate their productions sites to states with higher safety standard norms. ${ }^{101}$ Walt Disney publicly stated in May 2013, following the disaster, that, in order to maintain the international labour standards it has set for itself and its employees, it must cease the production of Disney products in states where the risk for violating these standards is too high, Bangladesh included. ${ }^{102}$

However, surprisingly, this decision of the Walt Disney Company encountered sharp public criticism. The criticism was that millions of people are dependent in a "Post-Rana Plaza World”' (2015) 87 Int Labor Work-Class 165.

100 Stammers (n 50).

101 Puck Lo, 'H\&M Responds Slowly to Bangladesh Factory Collapse Killing 1,000' CorpWatch (San Francisco, 19 May 2013) <http://corpwatch.org/article.php?id=15840> accessed 27 September 2016.

102 The Walt Disney Company, 'Permitted Sourcing Country Policy - March 2013' (2013) $<$ https://ditm-twdc-us.storage.googleapis.com/Permitted-Sourcing-Countries-Document. pdf $>$ accessed 27 September 2016. 
on western corporations in the garment sector for their income, especially rural populations which do not have alternative employment opportunities. ${ }^{103}$ Disney's choice to relocate production sites thus does not lead to better living conditions, and might even harm the local population's social mobility. Disney's claims that the risk to human lives justifies the potential economic damage to developing states was thus not sympathetically accepted. ${ }^{104}$ The prevalent stance was that TNCs should maintain their supply chains as is, in order to support developing economies, but nevertheless take an active role in ameliorating working conditions while upholding international standards. ${ }^{105}$ This stance perceives TNCs as substantial actors in the design and formulation of local human rights regimes and attributes them with irrevocable social responsibilities once they have chosen to utilise the commercial benefits that come along with relocating production sites to post-colonial settings.

The conceptualisation of TNCs' regulatory role as carriers of legal transplants in the field of human rights, and so as agents of change, clarifies the additional contribution of the legal transplants paradigm. The discussion of corporate social responsibility within the soft-law paradigm, as well as under the old governance assumptions, primarily focuses on the ways in which it contributes to restraining TNCs' destructive power with regard to human rights. The basic assumption underlying this discussion is that the TNC is unequivocally an obstacle to the promotion of human rights norms.

Conversely, the discussion of corporate social responsibility within the legal transplant paradigm offers a different perspective, which focuses on the possible contribution of TNCs as significant agents of change to the diffusion of human rights within the statist boundaries. Under this paradigm, therefore, one can move from the normative discussion of legal liability to empirical questions, such as the effectiveness of legal transplants and the necessary means to an efficient diffusion of norms and thus to come one step closer to the effective institutionalisation of human rights regimes where they are lacking.

104 The Walt Disney Company (n 102); Michael H Posner, 'Disney and Other Big Brand Need to Address the Real Challenges of Outsourcing' The New York Times (New York, 2 May 2013) <http://www.nytimes.com/roomfordebate/2013/05/02/when-does-corporate-responsibilitymean-abandoning-ship/disney-and-other-big-brands-need-to-address-the-real-challengesto-outsourcing> accessed 27 September 2016.

105 Kimberly Ann Elliott, 'Cutting Off Trade with Bangladesh Would Hurt Workers' The New York Times (New York, 2 May 2013) <http://www.nytimes.com/roomfordebate/2013/05/02/whendoes-corporate-responsibility-mean-abandoning-ship/cutting-off-trade-with-bangladeshwould-hurt-workers> accessed 27 September 2016. 


\section{Conclusion}

The case study of Rana Plaza and the collaborative initiatives formulated by TNCs and NGOs that ensued reflect some necessary changes in perception within the international human rights scholarship. As new governance scholars have begun to suggest in certain contexts, non-state actors can no longer be regarded as objects of international regulation alone, but should be treated as equal partners in international governance.

The novel angle that the present article offers is to consider the corporate actor as a regulator and an agent of change in the field of international human rights law, and to characterise its regulatory role as a form of legal transplantation. The theoretical merit of this approach is that it regards TNCs as active participants in the design and formulation of human rights regimes, rather than precarious objects that need to be regulated.

Legal transplants theories, which primarily discuss the way that systems of law are created and evolve, have often underestimated this role of private actors, much less of private corporations, in institutionalising legal norms and their contribution to their design. Although recognising a more diverse set of actors involved in the diffusion of law, legal transplants theories have, in many respects, remained state-centric. In the same manner, sociologists of human rights discussing the mobilisation processes of human rights have also been focusing primarily on state mechanisms influencing the diffusion of human rights amongst states and within them.

Thus, by conceptualising TNCs as carriers of legal transplants and concretising such a conception through the case study of Rana Plaza, this article joins new governance claims with regard to the perception of private actors' role in the operation of governance and regulation. Once TNCs' role as carriers of legal transplants, and hence as agent of change in the field of human rights, is seriously considered, new avenues of research can be paved to support policy decisions on the global level with regard to the promotion of human rights regimes, as well as to help develop critical thinking as to the pitfalls of such private transnational regulation. Furthermore, recognising TNCs' regulatory role in the field of human rights raises normative questions with regard to our understanding of human rights theories and doctrines, and the way in which human rights regimes are formed in an era of dominant transnational corporate power. 